African Crop Science Journal by African Crop Science Society is licensed under a Creative Commons Attribution 3.0 Uganda License. Based on a work at www.ajol.info/ and www.bioline.org.br/cs DOI: https://dx.doi.org/10.4314/acsj.v27i1.6

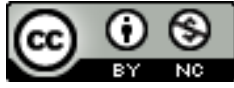

\title{
EFFECT OF COOKING AND EXTRACTION METHOD ON OLEAGINOUS CUCURBIT SEED OILS QUALITY
}

\author{
A.L.LOUKOU, A.E. AGBO, S.TRAORE, B.I.A. ZORO'1, G. LOGNAY² and K. BROU \\ Food Science and Technology Department, Nangui Abrogoua University, P. O. Box 801 Abidjan 02, \\ Cote d'Ivoire \\ ${ }^{1}$ Plant production, Crop Husbandry and Breeding Unit Department; University Nangui Abrogoua, \\ P. O. Box 801 Abidjan 02, Cote d'Ivoire \\ ${ }^{2}$ Analytical chemistry, Gembloux Agro Bio Tech, University of Liege, Passage des Deportes, 2, \\ B-5030 Gembloux, Belgium \\ Corresponding author: loukouletine@yahoo.fr
}

(Received 15 April, 2018; accepted 20 February, 2019)

\begin{abstract}
In sub-Saharan Africa, Lagenaria siceraria seeds are cooked before consumption. Cooking seed may alter their chemical composition, leading to changes in their health benefits. Thus, this study aimed at determining the effect of cooking of $L$. siceraria seeds on their edible oil quality. Heat treatments were performed as roasted $\left(100\right.$ and $\left.125^{\circ} \mathrm{C}\right)$ and boiled $(10,35,60$ and $90 \mathrm{~min})$. Then oils were extracted with petroleum ether solvent and hot-water flotation process. Peroxide and acid index, and fatty acids composition were evaluated. With the hot-water flotation process, roasting and boiling had no significant effect on acid index and fatty acids composition. However, peroxide values varied from 1.1 to $2.9 \mathrm{meqO}_{2} \mathrm{~kg}^{-1}$ oil. The highest peroxides values were revealed at 90 and $60 \mathrm{~min}$, respectively, in seeds roasted at 100 and $125^{\circ} \mathrm{C}$. With solvent extraction, roasting and boiling affected only peroxide values and fatty acids composition. The highest peroxide values were reached after $10 \mathrm{~min}$ of ebullition of roasted seeds, both at 100 and $125^{\circ} \mathrm{C}$. Saturated and polyunsaturated fatty acid contents increased after $10 \mathrm{~min}$ of boiling of seeds roasted at 100 and $125^{\circ} \mathrm{C}$; then decreased to reach the initial content. But, the monounsaturated fatty acids content decreased after $10 \mathrm{~min}$ of boiling, and then increased to reach the initial content. The highest values of peroxides and polyunsaturated fatty acids contents were observed with solvent extraction compared to hot-water flotation method. Cooking of $L$. siceraria seeds does not alter the quality of their oil; solvent extraction makes their oil highly unstable.
\end{abstract}

Key Words: Fatty acids, Lagenaria siceraria, quality indexes

\section{RESUME}

En Afrique subsaharienne, les graines de Lagenaria siceraria sont consommées cuites. La cuisson des graines peut altérer leur composition chimique, entraînant des changements quant à leurs bienfaits pour la santé. Ainsi, cette étude visait à déterminer l'effet de la cuisson des graines de L. siceraria sur 
la qualité de leurs huiles. Les traitements thermiques ont été effectués: torréfaction $\left(100\right.$ et $\left.125^{\circ} \mathrm{C}\right)$ et ébullition (10,35, 60 et $90 \mathrm{~min}$ ). Les huiles ont, ensuite, été extraites avec l'éther de pétrole et par un procédé de flottation à l'eau chaude. L'indice de peroxyde et d'acide ainsi que la composition en acides gras ont été évalués. Avec le procédé de flottation à l'eau chaude, la torréfaction et l'ébullition n'ont eu aucun effet sur l'indice d'acide et la composition en acides gras. Cependant, les valeurs de peroxyde variaient de 1,1 à 2,9 méqO2.kg d'huile. Les valeurs les plus élevées de peroxydes ont été révélées à 90 et 60 min respectivement dans les graines torréfiées à 100 et $125^{\circ} \mathrm{C}$. Avec l'extraction par solvant, la torréfaction et l'ébullition n'ont affecté que les valeurs de peroxyde et la composition en acides gras. Les valeurs de peroxyde les plus élevées ont été atteintes après 10 min d'ébullition des graines grillées à 100 et à $125^{\circ} \mathrm{C}$. Les teneurs en acides gras saturés et polyinsaturés ont augmenté après 10 min d'ébullition des graines torréfiées à 100 et $125^{\circ} \mathrm{C}$ puis ont diminué pour atteindre leurs teneurs initiales lorsque le temps d'ébullition a augmenté. Mais, la teneur en acides gras monoinsaturés a diminué après 10 minutes d'ébullition, puis a augmenté pour atteindre la teneur initiale. Les valeurs les plus élevées des teneurs en peroxydes et en acides gras polyinsaturés ont été observées avec l'extraction par le solvant comparé à la méthode de flottation à l'eau chaude. Cuire les graines de $L$. siceraria n'altère pas la qualité de leur huile ; l'extraction par le solvant rend leur huile hautement instable.

Mots Clés: Acides gras, Lagenaria siceraria, indice de qualité

\section{INTRODUCTION}

Lagenaria siceraria (Molina) Standl. belongs to cucurbitaceous family, is one of the most widely distributed and consumed cucurbit in both rural and urban areas in sub-Saharan Africa. Lagenaria siceraria is the most widely cultivated oleaginous cucurbit for its high agronomic potential (Achigan Dako et al., 2006). It exhibits the richest macronutrient contents, and contains $40 \%$ proteins and 54 $\%$ fat (Loukou et al., 2011). Loukou et al. (2011) have revealed that in L. siceraria oils, polyunsaturated fatty acids rate varies between 56.41 and $66.70 \%$. The high content of essential fatty acids in this crop contributes to human tissues development (NtsombohNtsefong et al., 2016). In addition, Milind and Satbir (2011) reported that Lagenaria siceraria seed oil has several beneficial health effects.

Lagenaria siceraria seeds are consumed as a soup thickener called pistache soup in Côte d'Ivoire, and egussi soup in Nigeria. In Côte d'Ivoire, to prepare this sauce the seeds are decorticated, roasted, ground made into dough, and boiled. The seeds are also grilled for snack (Morimoto and Mvere, 2004). However, heat treatment like baking, grilling and pan frying can deteriorate fats and oils. But, most information on $L$. siceraria concern raw seeds and they do not reflect cooked seed nutritional quality (Badifu, 2001). So, it is necessary to evaluate cooked seed composition, particularly variation in oil during cooking process. Indeed, oil qualities are determined by their fatty acids composition, which may be affected by heat treatment.

Onyeike and Acheru (2002) showed that the high degree of unsaturation in the oil led to the low resistance to oxidative rancidity. According to Richardsa et al. (2005), lipid oxidation is probably the most important factor affecting the quality of edible oils. The hydroperoxides produced by lipid oxidation can be decomposed into various smaller molecules such as aldehydes, ketones, alcohols and carboxylic acids. Some of these volatile compounds impact the favour even at very low concentrations and degrading. Oils or foods become either unpalatable or unhealthy to consumption. Moreover, the ingestion of rancid lipids has been linked to the development or exacerbation of many diseases, such as atherosclerosis, cataracts, diarrhea, kidney disease and heart disease, and can cause cellular membrane damage, nausea, 
neurodegeneration and carcinogenesis (Richardsa et al., 2005).

This study was conducted to evaluate the nutritional quality of the oil from Lagenaria siceraria roasted and boiled seeds in order to ascertain their suitability for consumption.

\section{MATERIALS AND METHODS}

In 2012, seeds of oleaginous, $L$. siceraria were extracted from mature fruits collected from experimental farm of Nangui Abrogoua University, Cote d'Ivoire. The seeds were sundried for 7 days and shelled manually to obtain the kernels. The sundried seeds were divided in two categories of unprocessed (kept as control) and cooked (roasted and boiled).

Roasting process. The seeds (1200 g) were roasted in an air-oven at temperatures of 100 and $125^{\circ} \mathrm{C}$ for $25 \mathrm{~min}$ (Badifu, 2001). During roasting, kernels were turned every after $5 \mathrm{~min}$ using spatula for uniform roasting. After roasting, the seeds were ground using a laboratory crusher (Culatti, France) and stored in an airtight plastic container at $-20{ }^{\circ} \mathrm{C}$ for further analysis.

Boiling process. One hundred grammes of roasted seeds of $L$. siceraria were put in beaker containing $500 \mathrm{ml}$ of boiled distillated water. The cooking was carried out at $98{ }^{\circ} \mathrm{C}$ during 10, 35, 60 and $90 \mathrm{~min}$; while stirring occasionally using Spatula. This technique was performed in duplicate. After boiling, the samples were cooled at room temperature (20 $\left.-25^{\circ} \mathrm{C}\right)$. Two lots were constituted. Each lot contained raw seeds, roasted seeds at 100 and $125^{\circ} \mathrm{C}$; and boiled seeds during $0,35,60$ and $90 \mathrm{~min}$. Boiled samples of both lots were lyophilised using lyophiliser.

Oil extraction. The oils from the first lot were extracted with petroleum ether, using a Soxhlet apparatus (AOAC, 2000). The extracted oils were packaged in brown bottles for analysis (named solvent extraction). The oils of the second lot were extracted by hot-water flotation according to Warra (2011) with some modifications. A hundred $\mathrm{ml}$ of boiling water were added to $20 \mathrm{mg}$ of sample and stirred for $15 \mathrm{~min}$. After cooling the upper oil layer was collected, dried by heating and also packaged in dark glass bottles in refrigerator.

Chemical analyses. Peroxide value $(\mathrm{Cd} 8 \mathrm{~b}-$ 90) and acid value (NF T60-204) were determined using AOCS (1997) methods. Fatty acids composition was also evaluated; whereby $10 \mathrm{mg}$ of oil were first converted in their methyl esters (FAMEs) with a mixture of boron trifluoride (BF3) and methanol (140 $\mathrm{mg} \mathrm{ml}^{-1}$ ), according to the method of Morrison and Smith (1964). The extracted FAMEs were dissolved in pure hexane for gas chromatography analysis (HP 6890, Agilent technologies Brussels, Belgium) with flame ionisation detection. One $\mu 1$ aliquot of FAME sample was injected onto a Varian CP 9205 (Sint-Katelijne Waver, Belgium) capillary column (30 m length, $0.25 \mathrm{~mm}$ diameter, 0.25 $\mu \mathrm{m}$ film thickness). A standard mixture of 37 fatty acids (Supelco, Bellefonte, PA, USA) was used for identification. The identification was confirmed by gas chromatography/mass spectrometry.

Statistical analysis. All chemical analyses data were statistically analysed by one way analysis of variance (ANOVA). Means were compared by LSD test. The analyses were performed using Statistica 7.1 software (StatSoft, Poland).

\section{RESULTS}

Roasting and boiling. Table 1 presents peroxide and acid index values of $L$. siceraria oils from roasted and boiled seeds extracted with solvent; while Table 2 presents their fatty acids composition. Results showed that the cooking processes had significant effects on peroxide values and fatty acids composition. On the other hand, there was no significant 


\section{A.L. LOUKOU et al.}

effect on acid index. Roasting at $125^{\circ} \mathrm{C}$ had significantly reduced peroxide values of oils extracted with the solvent. On the other hand, peroxide values significantly increased until certain boiling time beyond which they decreased. The highest peroxide values were reached after $10 \mathrm{~min}$ of ebullition of roasted seeds for both $100{ }^{\circ} \mathrm{C}\left(4.49\right.$ meq $\mathrm{O}_{2} \mathrm{~kg}^{-1}$ oil $)$ and $125^{\circ} \mathrm{C}$ (4.12 meq $\mathrm{O}_{2} \mathrm{~kg}^{-1}$ oil).

For fatty acids composition, the results have showed that the major fatty acids in $L$. siceraria seed oils were linoleic acid (574 to $614,8 \mathrm{~g} \mathrm{~kg}^{-1}$ ), oleic acid (142.7 to $185.9 \mathrm{~g} \mathrm{~kg}^{-}$ ${ }^{1}$ ), and palmitic acid (153.4 to $162.1 \mathrm{~g} \mathrm{~kg}^{-1}$ ) (Table 2). Roasting ( 100 and $125^{\circ} \mathrm{C}$ during 25 min) and boiling (during 10, 35, 60 and 90 min) had a significant effect on fatty acids composition of the oils. The variation in fatty acids composition occurred with the change of peroxide values. Saturated and polyunsaturated fatty acids contents increased after $10 \mathrm{~min}$ of boiling; then returned to the original contents when the boiling time increase for seeds roasted at 100 and $125{ }^{\circ} \mathrm{C}$. The monounsaturated fatty acids content decreased after $10 \mathrm{~min}$ of boiling (185.7 to $142.7 \mathrm{~g} \mathrm{~kg}^{-1}$ ) and then returned to the original contents.

Table 3 presents peroxide and acid index values of $L$. siceraria oils from roasted and boiled seeds extracted by hot-water flotation and Table 4 presents their fatty acids composition. The denomination "nd" was attributed to samples whose oils could not be collected after hot-water flotation process.

During cooking, results showed no change in acid index values, but there was a significant effect in peroxide values. In these oils, peroxide values significantly increased until certain boiling time (90 min for seeds roasted at 100 ${ }^{\circ} \mathrm{C}$ and $60 \mathrm{~min}$ for seeds roasted at $125^{\circ} \mathrm{C}$ ); beyond which they decreased. Indeed, the highest peroxides values were revealed at 90 min for seeds roasted at $100{ }^{\circ} \mathrm{C}\left(2.94\right.$ meq $\mathrm{O}_{2}$ $\mathrm{kg}^{-1}$ oil) and 60 min for seeds roasted at 125 ${ }^{\circ} \mathrm{C}$ (2.31 meq $\mathrm{O}_{2} \mathrm{~kg}^{-1}$ oil). The results have also showed that the major fatty acids in these oils were linoleic acid (568.1 to $600.5 \mathrm{~g} \mathrm{~kg}^{-1}$ ), oleic acid (166.2 to $182.2 \mathrm{~g} \mathrm{~kg}^{-1}$ ), and 
TABLE 2. Fatty acids composition of Lagenaria siceraria oil extracted with solvent during seeds processing

\begin{tabular}{|c|c|c|c|c|c|c|c|c|c|c|c|}
\hline \multirow[t]{4}{*}{ Fatty acid $\left(\mathrm{g} \mathrm{kg}^{-1}\right)$} & \multirow{4}{*}{$\begin{array}{l}\text { Untreated } \\
\text { seeds } \\
\text { (control) }\end{array}$} & \multicolumn{10}{|c|}{ Cooking process } \\
\hline & & \multicolumn{5}{|c|}{ Roasting at $100^{\circ} \mathrm{C}$ during $25 \mathrm{~min}$} & \multicolumn{5}{|c|}{ Roasting at $125^{\circ} \mathrm{C}$ during $25 \mathrm{~min}$} \\
\hline & & \multicolumn{5}{|c|}{ Boiling times (min) } & \multicolumn{5}{|c|}{ Boiling times (min) } \\
\hline & & 0 & 10 & 35 & 60 & 90 & 0 & 10 & 35 & 60 & 90 \\
\hline C16:0 & $153.4 \pm 0.4^{\mathrm{c}}$ & $154.3 \pm 0.5^{\mathrm{c}}$ & $158.4 \pm 0.5^{\mathrm{ab}}$ & $152.9 \pm 0.1^{\mathrm{c}}$ & $155.0 \pm 1.9^{\mathrm{bc}}$ & $153.8 \pm 0.2^{\mathrm{c}}$ & $155.2 \pm 1.0^{\mathrm{bc}}$ & $162.1 \pm 3.5^{\mathrm{a}}$ & $154.5 \pm 0.2^{\mathrm{bc}}$ & $154.5 \pm 0.6^{\mathrm{bc}}$ & $155.0 \pm 0.8^{\mathrm{bc}}$ \\
\hline C18:0 & $76.4 \pm 1.0$ & $75.2 \pm 0.2$ & $74.7 \pm 0.2$ & $76.1 \pm 0.0$ & $70.2 \pm 4.3$ & $73.6 \pm 0.3$ & $74.8 \pm 0.5$ & $76.3 \pm 0.2$ & $75.6 \pm 0.0$ & $74.8 \pm 0.5$ & $74.6 \pm 0.3$ \\
\hline C20:0 & $3.5 \pm 0.1$ & $3.5 \pm 0.1$ & $3.3 \pm 0.0$ & $3.5 \pm 0.1$ & $3.8 \pm 0.2$ & $3.8 \pm 0.3$ & $3.5 \pm 0.0$ & $3.4 \pm 0.0$ & $3.6 \pm 0.0$ & $3.4 \pm 0.0$ & $3.5 \pm 0.0$ \\
\hline $\mathrm{C} 18: \ln 9$ & $170.0 \pm 14.9^{\mathrm{a}}$ & $185.7 \pm 0.1^{\mathrm{a}}$ & $142.7 \pm 0.1^{\mathrm{b}}$ & $179.6 \pm 0.6^{\mathrm{a}}$ & $177.9 \pm 1.2^{\mathrm{a}}$ & $170.3 \pm 1.7^{\mathrm{a}}$ & $185.9 \pm 0.1^{\mathrm{a}}$ & $151.1 \pm 0.3^{\mathrm{b}}$ & $176.9 \pm 0.3^{\mathrm{a}}$ & $183.9 \pm 0.1^{\mathrm{a}}$ & $185.0 \pm 0.1^{\mathrm{a}}$ \\
\hline C18:2n6 & $576.0 \pm 0.5^{\mathrm{c}}$ & $575.1 \pm 0.1^{c}$ & $614.8 \pm 0.7^{\mathrm{a}}$ & $580.4 \pm 0.3^{c}$ & $580.1 \pm 9.6^{c}$ & $577.4 \pm 2.9^{c}$ & $574.0 \pm 0.2^{\mathrm{c}}$ & $597.4 \pm 3.8^{\mathrm{b}}$ & $582.9 \pm 0.5^{\mathrm{c}}$ & $577.8 \pm 0.1^{\mathrm{c}}$ & $576.8 \pm 1.1^{\mathrm{c}}$ \\
\hline C18:3n3 & $1.0 \pm 0.1$ & $1.0 \pm 0.0$ & $1.2 \pm 0.1$ & $1.1 \pm 0.1$ & $1.1 \pm 0.0$ & $1.0 \pm 0.0$ & $1.2 \pm 0.1$ & $1.3 \pm 0.1$ & $1.1 \pm 0.0$ & $1.1 \pm 0.0$ & $1.1 \pm 0.1$ \\
\hline TSFAs & $233.3 \pm 0.5^{\mathrm{bc}}$ & $233.3 \pm 0.5^{\mathrm{bc}}$ & $236.5 \pm 0.3^{b}$ & $232.6 \pm 0.2^{\mathrm{cd}}$ & $229.0 \pm 2.2^{\mathrm{d}}$ & $231.2 \pm 0.9^{\mathrm{cd}}$ & $233.5 \pm 0.5^{\mathrm{bc}}$ & $241.9 \pm 3.2^{\mathrm{a}}$ & $233.7 \pm 0.2^{\mathrm{bc}}$ & $232.7 \pm 0.1^{\mathrm{bcd}}$ & $233.0 \pm 0.5^{\mathrm{bc}}$ \\
\hline TMUFA $s$ & $170.0 \pm 14.9^{\mathrm{a}}$ & $185.7 \pm 0.1^{\mathrm{a}}$ & $142.7 \pm 0.1^{\mathrm{b}}$ & $179.6 \pm 0.6^{\mathrm{a}}$ & $177.9 \pm 8.7^{\mathrm{a}}$ & $170.3 \pm 1.7^{\mathrm{a}}$ & $185.9 \pm 0.7^{\mathrm{a}}$ & $151.1 \pm 0.3^{\mathrm{b}}$ & $176.9 \pm 0.3^{\mathrm{a}}$ & $183.9 \pm 0.1^{\mathrm{a}}$ & $185.0 \pm 0.1^{\mathrm{a}}$ \\
\hline TPUFAs & $577.0 \pm 0.5^{\mathrm{c}}$ & $576.2 \pm 0.1^{\mathrm{c}}$ & $616.0 \pm 0.5^{\mathrm{a}}$ & $581.4 \pm 0.4^{\mathrm{c}}$ & $581.2 \pm 9.6^{c}$ & $578.4 \pm 2.9^{c}$ & $575.2 \pm 0.3^{\mathrm{c}}$ & $598.7 \pm 3.7^{b}$ & $584.1 \pm 0.6^{c}$ & $578.9 \pm 0.1^{\mathrm{c}}$ & $577.9 \pm 1.2^{\mathrm{c}}$ \\
\hline
\end{tabular}


A.L. LOUKOU et al.

palmitic acid (147.1 to $160.6 \mathrm{~g} \mathrm{~kg}^{-1}$ ). They also showed that roasting and boiling had no significant effect on oils recovered after hotwater flotation.

Extraction methods. Table 5 shows peroxide and acid index values of Lagenaria siceraria oil extracted with solvent and recovered after hot-water flotation. The results showed significant different $(\mathrm{P}<0.05)$ between peroxide values of the both extraction methods during cooking while there are no significant difference for acid index values. The highest values of peroxides values were observed in oils extracted with the solvent (2.26 to 4.49 meq $\mathrm{O}_{2} \mathrm{~kg}^{-1}$ oil), and the lowest in oils extracted by hot-water flotation (1.14 to 2.94 meq $\mathrm{O}_{2}$ $\mathrm{kg}^{-1}$ oil).

Fatty acids composition of oil extracted following two different methods is presented in Table 6. Palmitic (147.1 to $162.1 \mathrm{~g} \mathrm{~kg}^{-1}$ ) and stearic acids (70.2 to $\left.80.1 \mathrm{~g} \mathrm{~kg}^{-1}\right)$ were the most representative saturated fatty acids (SFAs) in Lagenaria siceraria oil; while arachidic acids ( 1.0 to $1.4 \mathrm{~g} \mathrm{~kg}^{-1}$ ) were present in low concentrations for all extracts used. Lagenaria siceraria oil contains mainly unsaturated fatty acids (UFAs) in both oils extracted with solvent and recovered after hotwater flotation. Oleic (142.7 to $185.7 \mathrm{~g} \mathrm{~kg}^{-1}$ ) and linoleic acids (567.0 to $614.8 \mathrm{~g} \mathrm{~kg}^{-1}$ ) were the major UFAs in all $L$. siceraria oil samples obtained by the two extraction methods.

The fatty acids content following extraction method in different cooking process was significantly different $(\mathrm{P}<0.05)$ in some cases. Indeed, for SFAs, the differences were observed when seeds were roasted at $100{ }^{\circ} \mathrm{C}$ and boiled during 10, 60 and $90 \mathrm{~min}$; and roasted at $125^{\circ} \mathrm{C}$ and boiled during 35 and 90 $\min$. For MUFAs, the differences were revealed when seeds were roasted at $100^{\circ} \mathrm{C}$ and boiled during $10 \mathrm{~min}$; and roasted at $125^{\circ} \mathrm{C}$ and boiled during 10, 35 and $90 \mathrm{~min}$. The highest SFAs and MUFAs contents were obtained in recovered oils after hot-water flotation process. For PUFA, the differences were observed when seeds were roasted at $100{ }^{\circ} \mathrm{C}$ 
TABLE 4. Fatty acids composition of Lagenaria siceraria oil extracted by hot-water flotation during seeds processing

\begin{tabular}{|c|c|c|c|c|c|c|c|c|c|c|c|}
\hline \multirow[t]{4}{*}{ Fatty acid $\left(\mathrm{g} \mathrm{kg}^{-1}\right)$} & \multirow{4}{*}{$\begin{array}{l}\text { Untreated } \\
\text { seeds } \\
\text { (control) }\end{array}$} & \multicolumn{10}{|c|}{ Cooking process } \\
\hline & & \multicolumn{5}{|c|}{ Roasting at $100^{\circ} \mathrm{C}$ during $25 \mathrm{~min}$} & \multicolumn{5}{|c|}{ Roasting at $125^{\circ} \mathrm{C}$ during $25 \mathrm{~min}$} \\
\hline & & \multicolumn{5}{|c|}{---- Boiling times (min) } & \multicolumn{3}{|c|}{-- - Boiling times (min) } & \multicolumn{2}{|c|}{-----} \\
\hline & & 0 & 10 & 35 & 60 & 90 & 0 & 10 & 35 & 60 & 90 \\
\hline C16:0 & nd & nd & $159.5 \pm 0.7^{\mathrm{a}}$ & $156.4 \pm .1^{\mathrm{a}}$ & $161.3 \pm 2.0^{\mathrm{a}}$ & $158.9 \pm 0.7^{\mathrm{a}}$ & nd & $160.6 \pm 2.2^{\mathrm{a}}$ & $159.0 \pm 1.4^{\mathrm{a}}$ & $147.1 \pm 20.4^{\mathrm{a}}$ & $159.5 \pm 0.5^{\mathrm{a}}$ \\
\hline $\mathrm{C} 18: 0$ & nd & nd & $79.6 \pm 0.0^{\mathrm{a}}$ & $79.6 \pm 0.3^{\mathrm{a}}$ & $78.8 \pm 0.0^{\mathrm{a}}$ & $78.8 \pm 0.9^{\mathrm{a}}$ & nd & $80.0 \pm 0.1^{\mathrm{a}}$ & $80.1 \pm 0.5^{\mathrm{a}}$ & $73.8 \pm 7.9^{\mathrm{a}}$ & $79.1 \pm 0.1^{\mathrm{a}}$ \\
\hline C20:0 & nd & nd & $3.9 \pm 0.2^{\mathrm{a}}$ & $3.9 \pm 0.0^{\mathrm{a}}$ & $3.8 \pm 0.0^{\mathrm{a}}$ & $3.9 \pm 0.2^{\mathrm{a}}$ & nd & $3.8 \pm 0.0^{\mathrm{a}}$ & $3.9 \pm 0.1^{\mathrm{a}}$ & $3.7 \pm 0.4^{\mathrm{a}}$ & $4.0 \pm 0.2^{\mathrm{a}}$ \\
\hline $\mathrm{C} 18: \ln 9$ & nd & nd & $182.2 \pm 0.3^{\mathrm{a}}$ & $180.0 \pm 0.5^{\mathrm{a}}$ & $179.0 \pm 0.4^{\mathrm{a}}$ & $174.5 \pm 0.8^{\mathrm{a}}$ & nd & $181.0 \pm 0.1^{\mathrm{a}}$ & $184.6 \pm 0.5^{\mathrm{b}}$ & $166.2 \pm 21.5^{\mathrm{a}}$ & $175.6 \pm 0.2^{b}$ \\
\hline C18:2n6 & nd & nd & $568.1 \pm 0.4^{b}$ & $569.8 \pm 0.1^{\mathrm{b}}$ & $571.4 \pm 2.2^{\mathrm{a}}$ & $570.8 \pm 4.6^{\mathrm{a}}$ & nd & $567.9 \pm 1.0^{\mathrm{b}}$ & $567.0 \pm .5^{\mathrm{b}}$ & $600.5 \pm 44.6^{\mathrm{a}}$ & $574.8 \pm 0.4^{b}$ \\
\hline C18:3n3 & nd & nd & $1.4 \pm 0.1^{\mathrm{a}}$ & $1.4 \pm 0.1^{\mathrm{a}}$ & $1.4 \pm 0.0^{\mathrm{a}}$ & $1.4 \pm 0.0^{\mathrm{a}}$ & nd & $1.3 \pm 0.2^{\mathrm{a}}$ & $1.3 \pm 0.1^{\mathrm{a}}$ & $1.2 \pm 0.2^{\mathrm{a}}$ & $1.4 \pm 0.1^{\mathrm{a}}$ \\
\hline TSFAs & nd & nd & $242.9 \pm 0.8^{\mathrm{a}}$ & $239.8 \pm 5.8^{\mathrm{a}}$ & $244.0 \pm 2.0^{\mathrm{a}}$ & $241.7 \pm 0.4^{\mathrm{a}}$ & nd & $244.4 \pm 2.1^{\mathrm{a}}$ & $243.0 \pm 1.7^{\mathrm{a}}$ & $224.5 \pm 27.9^{a}$ & $242.6 \pm 0.4^{\mathrm{a}}$ \\
\hline TMUFAs & nd & nd & $182.2 \pm 0.3^{\mathrm{a}}$ & $180.0 \pm 0.5^{\mathrm{a}}$ & $179.0 \pm 0.4^{\mathrm{a}}$ & $174.5 \pm 0.8^{\mathrm{a}}$ & nd & $181.0 \pm 0.1^{\mathrm{a}}$ & $184.6 \pm 0.5^{\mathrm{a}}$ & $166.2 \pm 21.5$ & $175.6 \pm 0.2^{b}$ \\
\hline TPUFAs & nd & nd & $569.4 \pm 0.3^{\mathrm{b}}$ & $571.1 \pm 0.0^{b}$ & $572.8 \pm 2.1^{\mathrm{a}}$ & $572.1 \pm 4.6^{\mathrm{a}}$ & nd & $569.1 \pm 1.2^{\mathrm{b}}$ & $568.3 \pm 0.6^{b}$ & $601.6 \pm 44.8^{\mathrm{a}}$ & $576.1 \pm 0.2^{\mathrm{a}}$ \\
\hline
\end{tabular}

Different letters within the same line indicate significant differences among cooking process ( $\mathrm{P}<0.05) . \mathrm{C} 16: 0$ : Palmitic acid, C18:0:Stearic acid, C20:0 Arachic acid; C18:1n9: Oleic aci; C18:2n6: Linoléic acid; C18:3n3: Linolénic acid; TSFA = Total Saturated fatty acids; TMUFA= Total Monounsaturated fatty acids; TPUFA = Total Polyunsaturated fatty acids 


\section{A.L. LOUKOU et al.}

and boiled during 10, 35 and $90 \mathrm{~min}$; and roasted at $125^{\circ} \mathrm{C}$ and boiled during 35 and 90 min. The highest PUFAs contents were obtained in oils extracted with solvent (574.0 to $614.8 \mathrm{~g} \mathrm{~kg}^{-1}$ ) and the lowest in oils extracted by hot-water flotation (567.0 to $\left.600.2 \mathrm{~g} \mathrm{~kg}^{-1}\right)$.

\section{DISCUSSION}

In this study peroxide values increase with extended boiling duration (10 min for oils extracted with solvent and $90 \mathrm{~min}$ for roasting at $100{ }^{\circ} \mathrm{C}$ and $60 \mathrm{~min}$ for roasting at $125^{\circ} \mathrm{C}$ for oils extracted by hot-water flotation) and decrease thereafter. The increase of peroxide value to reach the maximum and decrease could be due to the fact that the peroxides are labile intermediate compounds which decompose into several secondary oxidation products such as as aldehydes, ketones and esters. This result is in concordance to that of Abramovic et al. (2005) studies who also showed that during oxidation, the peroxide value may reach a maximum and then decreases. The reduction in the peroxide values occured earlier for oil extracted with the solvent and later for the oil recovered after ebullition. This means that oil extracted with the solvent deteriorates faster than that recovered after hot-water flotation. Nevertheless, during cooking both studied oils had peroxide values below limit of CODEXSTAN 210 (1999) which is inferior to 15 milliequivalents of active oxygen per $\mathrm{kg}$ for virgin oils and inferior to 10 milliequivalents active oxygen per $\mathrm{kg}$ for cooking oil (O'Brien, 2009). In general, the lower the peroxide value, the better the quality of the oil is. Lagenaria siceraria seeds are consumed as a thickener soup in Côte d'Ivoire and in Nigeria. These seeds are cooked before eating. It is generally known that fats and oils can be deteriorated under heat. The assessment of peroxide and acid index values could indicate if sauce made from this cooked seeds or the oils present in this sauce are suitable for consumption whatever the cooking process. Peroxide value is used only in the case of oil that is not rancid (Popa et al., 2017). It is applicable for 
TABLE 6. Changes in fatty acids composition of Lagenaria siceraria oil extracted with solvent and by hot-water flotation

\begin{tabular}{|c|c|c|c|c|c|c|c|c|c|c|c|c|}
\hline \multirow[t]{3}{*}{ Fatty acid $\left(\mathrm{g} \cdot \mathrm{kg}^{-1}\right)$} & \multirow[t]{3}{*}{ Extraction methods } & \multirow{4}{*}{$\begin{array}{l}\text { Untreated } \\
\text { seeds } \\
\text { (control) }\end{array}$} & \multicolumn{10}{|c|}{ Cooking process } \\
\hline & & & \multicolumn{5}{|c|}{ Roasting at $100^{\circ} \mathrm{C}$ during $25 \mathrm{~min}$} & \multicolumn{5}{|c|}{ Roasting at $125^{\circ} \mathrm{C}$ during $25 \mathrm{~min}$} \\
\hline & & & -- & --1 & Boiling times $(\mathrm{m}$ & in) - & -- & -- & — Boiliı & ing times $(\mathrm{min})$ & 1) - & --- \\
\hline & & & 0 & 10 & 35 & 60 & 90 & 0 & 10 & 35 & 60 & 90 \\
\hline \multirow[t]{2}{*}{ Palmitic (C16:0) } & Solvent & $153.4 \pm 0.4$ & $154.3 \pm 0.5$ & $158.4 \pm 0.5^{\mathrm{a}}$ & $152.9 \pm 0.1^{\mathrm{a}}$ & $155.0 \pm 1.9^{\mathrm{a}}$ & $153.8 \pm 0.2^{\mathrm{b}}$ & $155.2 \pm 1.0$ & $162.1 \pm 3.5^{\mathrm{a}}$ & $154.5 \pm 0.2^{\mathrm{b}}$ & $154.5 \pm 0.6^{\mathrm{a}}$ & $155.0 \pm 0.8^{\mathrm{b}}$ \\
\hline & Hot-water flotation & nd & nd & $159.5 \pm 0.7^{\mathrm{a}}$ & $156.4 \pm 6.1^{\mathrm{a}}$ & $161.3 \pm 2.0^{\mathrm{a}}$ & $158.9 \pm 0.7^{\mathrm{a}}$ & nd & $160.6 \pm 2.2^{\mathrm{a}}$ & $159.0 \pm 1.4^{\mathrm{a}}$ & $147.1 \pm 20.4^{\mathrm{a}}$ & $159.5 \pm 0.5^{\mathrm{a}}$ \\
\hline \multirow[t]{2}{*}{ Stearic (C18:0) } & Solvent & $76.4 \pm 1.0$ & $75.2 \pm 0.2$ & $74.7 \pm 0.2^{\mathrm{b}}$ & $76.1 \pm 0.0^{\mathrm{b}}$ & $70.2 \pm 4.3^{\mathrm{a}}$ & $73.6 \pm 0.3^{b}$ & $74.8 \pm 0.5$ & $76.3 \pm 0.2^{b}$ & $75.6 \pm 0.0^{\mathrm{b}}$ & $74.8 \pm 0.5^{\mathrm{a}}$ & $74.6 \pm 0.3^{b}$ \\
\hline & Hot-water flotation & nd & nd & $79.6 \pm 0.0^{\mathrm{a}}$ & $79.6 \pm 0.3^{\mathrm{a}}$ & $78.8 \pm 0.0^{\mathrm{a}}$ & $78.8 \pm 0.9^{\mathrm{a}}$ & nd & $80.0 \pm 0.1^{\mathrm{a}}$ & $80.1 \pm 0.5^{\mathrm{a}}$ & $73.8 \pm 7.9^{\mathrm{a}}$ & $79.1 \pm 0.1^{\mathrm{a}}$ \\
\hline \multirow[t]{2}{*}{ Arachidic $(\mathrm{C} 20: 0)$} & Solvent & $3.5 \pm 0.1$ & $3.5 \pm 0.1$ & $3.3 \pm 0.0^{\mathrm{b}}$ & $3.5 \pm 0.1^{\mathrm{a}}$ & $3.8 \pm 0.2^{\mathrm{a}}$ & $3.8 \pm 0.3^{\mathrm{a}}$ & $3.5 \pm 0.0$ & $3.4 \pm 0.0^{\mathrm{b}}$ & $3.6 \pm 0.0^{\mathrm{a}}$ & $3.4 \pm 0.0^{\mathrm{a}}$ & $3.5 \pm 0.0^{\mathrm{a}}$ \\
\hline & Hot-water flotation & nd & nd & $3.9 \pm 0.2^{\mathrm{a}}$ & $3.9 \pm 0.0^{\mathrm{a}}$ & $3.8 \pm 0.0^{\mathrm{a}}$ & $3.9 \pm 0.2^{\mathrm{a}}$ & nd & $3.8 \pm 0.0^{\mathrm{a}}$ & $3.9 \pm 0.1^{\mathrm{a}}$ & $3.7 \pm 0.4^{\mathrm{a}}$ & $4.0 \pm 0.2^{\mathrm{a}}$ \\
\hline \multirow[t]{2}{*}{ Oleic (C18:1n9) } & Solvent & $170.0 \pm 2.1$ & $185.7 \pm 0.1$ & $142.7 \pm 0.1^{\mathrm{b}}$ & $179.6 \pm 0.6^{\mathrm{a}}$ & $177.9 \pm 1.2^{\mathrm{a}}$ & $170.3 \pm 1.7^{\mathrm{a}}$ & $185.9 \pm 0.1$ & $151.1 \pm 0.3^{b}$ & $176.9 \pm 0.3^{\mathrm{a}}$ & $183.9 \pm 0.1^{\mathrm{a}}$ & $185.0 \pm 0.1^{\mathrm{a}}$ \\
\hline & Hot-water flotation & nd & nd & $182.2 \pm 0.3^{\mathrm{a}}$ & $180.0 \pm 0.5^{\mathrm{a}}$ & $179.0 \pm 0.4^{\mathrm{a}}$ & $174.5 \pm 0.8^{\mathrm{a}}$ & nd & $181.0 \pm 0.1^{\mathrm{a}}$ & $184.6 \pm 0.5^{\mathrm{b}}$ & $166.2 \pm 21.5^{\mathrm{a}}$ & $175.6 \pm .2^{\mathrm{b}}$ \\
\hline \multirow[t]{2}{*}{ Linoléic (C18:2n6) } & Solvent & $576.0 \pm 0.5$ & $575.1 \pm 0.1$ & $614.8 \pm 0.7^{\mathrm{a}}$ & $580.4 \pm 0.3^{\mathrm{a}}$ & $580.1 \pm 9.6^{\mathrm{a}}$ & $577.4 \pm 2.9^{\mathrm{a}}$ & $574.0 \pm 0.2$ & $597.4 \pm 3.8^{\mathrm{a}}$ & $582.9 \pm 0.5^{\mathrm{a}}$ & $577.8 \pm 0.1^{\mathrm{a}}$ & $576.8 \pm 1.1^{\mathrm{a}}$ \\
\hline & Hot-water flotation & nd & nd & $568.1 \pm 0.4^{\mathrm{b}}$ & $569.8 \pm 0.1^{\mathrm{b}}$ & $571.4 \pm 2.2^{\mathrm{a}}$ & $570.8 \pm 4.6^{\mathrm{a}}$ & nd & $567.9 \pm 1.0^{\mathrm{b}}$ & $567.0 \pm 0.5^{\mathrm{b}}$ & $600.5 \pm 44.6^{\mathrm{a}}$ & $574.8 \pm 0.4^{b}$ \\
\hline \multirow[t]{2}{*}{ Linolénic (C18:3n3) } & Solvent & $1.0 \pm 0.1$ & $1.0 \pm 0.0$ & $1.2 \pm 0.1^{\mathrm{a}}$ & $1.1 \pm 0.1^{\mathrm{a}}$ & $1.1 \pm 0.0^{\mathrm{a}}$ & $1.0 \pm 0.0^{\mathrm{a}}$ & $1.2 \pm 0.1$ & $1.3 \pm 0.1^{\mathrm{a}}$ & $1.1 \pm 0.0^{\mathrm{a}}$ & $1.1 \pm 0.0^{\mathrm{a}}$ & $1.1 \pm 0.1^{\mathrm{a}}$ \\
\hline & Hot-water flotation & nd & nd & $1.4 \pm 0.1^{\mathrm{a}}$ & $1.4 \pm 0.1^{\mathrm{a}}$ & $1.4 \pm 0.0^{\mathrm{a}}$ & $1.4 \pm 0.0^{\mathrm{a}}$ & nd & $1.3 \pm 0.2^{\mathrm{a}}$ & $1.3 \pm 0.1^{\mathrm{a}}$ & $1.2 \pm 0.2^{\mathrm{a}}$ & $1.4 \pm 0.1^{\mathrm{a}}$ \\
\hline \multirow[t]{2}{*}{ TSFAs } & Solvent & $233.3 \pm 0.5$ & $233.3 \pm 0.5$ & $236.5 \pm 0.3^{b}$ & $232.6 \pm 0.2^{\mathrm{a}}$ & $229.0 \pm 2.2^{\mathrm{b}}$ & $231.2 \pm 0.9^{\mathrm{b}}$ & $233.5 \pm 0.5$ & $241.9 \pm 3.2^{\mathrm{a}}$ & $233.7 \pm 0.2^{\mathrm{b}}$ & $232.7 \pm 0.1^{\mathrm{a}}$ & $233.0 \pm 0.5^{\mathrm{b}}$ \\
\hline & Hot-water flotation & nd & nd & $242.9 \pm 0.8^{\mathrm{a}}$ & $239.8 \pm 5.8^{\mathrm{a}}$ & $244.0 \pm 2.0^{\mathrm{a}}$ & $241.7 \pm 0.4^{\mathrm{a}}$ & nd & $244.4 \pm 2.1^{\mathrm{a}}$ & $243.0 \pm 1.7^{\mathrm{a}}$ & $224.5 \pm 27.9^{\mathrm{a}}$ & $242.6 \pm 0.4^{\mathrm{a}}$ \\
\hline \multirow[t]{2}{*}{ TMUFA } & Solvent & $170.0 \pm 2.1$ & $185.7 \pm 0.1$ & $142.7 \pm 0.1^{\mathrm{b}}$ & $179.6 \pm 0.6^{\mathrm{a}}$ & $177.9 \pm 8.7^{\mathrm{a}}$ & $170.3 \pm 1.7^{\mathrm{a}}$ & $185.9 \pm 0.7$ & $151.1 \pm 0.3^{\mathrm{b}}$ & $176.9 \pm 0.3^{\mathrm{b}}$ & $183.9 \pm 0.1^{\mathrm{a}}$ & $185.0 \pm 0.1^{\mathrm{a}}$ \\
\hline & Hot-water flotation & nd & nd & $182.2 \pm .3^{\mathrm{a}}$ & $180.0 \pm 0.5^{\mathrm{a}}$ & $179.0 \pm 0.4^{\mathrm{a}}$ & $174.5 \pm 0.8^{\mathrm{a}}$ & nd & $181.0 \pm 0.1^{\mathrm{a}}$ & $184.6 \pm 0.5^{\mathrm{a}}$ & $166.2 \pm 21.5^{\mathrm{a}}$ & $175.6 \pm 0.2^{b}$ \\
\hline \multirow[t]{2}{*}{ TPUFA } & Solvent & $577.0 \pm 0.5$ & $576.2 \pm 0.1$ & $616.0 \pm 0.5^{\mathrm{a}}$ & $581.4 \pm 0.4^{\mathrm{a}}$ & $581.2 \pm 9.6^{\mathrm{a}}$ & $578.4 \pm 2.9^{\mathrm{a}}$ & $575.2 \pm 0.3$ & $598.7 \pm 3.7^{\mathrm{a}}$ & $584.1 \pm 0.6^{\mathrm{a}}$ & $578.9 \pm 0.1^{\mathrm{a}}$ & $577.9 \pm 1.2^{\mathrm{a}}$ \\
\hline & Hot-water flotation & nd & nd & $569.4 \pm 0.3^{\mathrm{b}}$ & $571.1 \pm 0.0^{\mathrm{b}}$ & $5 / 2.8 \pm 2.1^{4}$ & $5 / 2.1 \pm 4.6^{a}$ & & $569.1 \pm 1.2^{\circ}$ & $568.3 \pm 0.6^{\circ}$ & & $5 / 6.1 \pm 0.2^{a}$ \\
\hline
\end{tabular}

In column for each parameter, means with the same superscript do not differ significantly $(\mathrm{P}>0.05 ; \mathrm{Nd}=$ not determined; $\mathrm{C} 16: 0$ : Palmitic acid; $\mathrm{C} 18: 0:$ Stearic acid; $\mathrm{C} 20: 0$ : Arachic acid C18:1n9: Oleic acid; C18:2n6: Linoléic acid; C18:3n3: Linolénic acid; TSFAs = Total saturated fatty acids; TMUFA = Total monounsaturated fatty acids; TPUFA = Total polyunsaturated fatty acids 
monitoring the formation of peroxides in the early stages of oxidation.

In this study, Acid index values were below $0.6 \mathrm{mg} \mathrm{KOH} \mathrm{g}^{-1}$ which is the permissible limit of Acid index value for all edible oils according to $\mathrm{FAO} / \mathrm{WHO}$ recommendation (AOCS, 2003). Acid index determination is often used as a general indication of the condition and edibility of oil.

Results showed no change in Lagenaria siceraria oils fatty acids composition recovered after hot-water flotation process. This is great because it has been established that food-processing techniques can affect fatty acid composition of oils when hardly subjected to successive heating (Lee et al., 2004). These results agreed with those of Mariod et al. (2012), who reported that saffower oil from seeds roasted at $180{ }^{\circ} \mathrm{C}$, during different times and boiled was not different from oil of untreated (raw) saffower seeds. On the other hand, the results indicated a variation in fatty acids content of the oils extracted with solvent after 10 min of boiling. The variation observed may be due to lipolytic activity, interactions between lipids and other constituents or processing conditions generate by the use of solvent. The fatty acid composition of oil is an indicator of its stability (Jung-Mi and Jeonghee, 2012). The high content of polyunsaturated fatty acids makes L. siceraria seed oil very unstable (Loukou et al., 2013), which expose it to polymerisation, oxidation and hydrolysis (Goswami et al., 2015).

Peroxide values were influenced by the extraction methods and the highest values were observed in oil extracted with the solvent. The higher peroxide obtained in oil extracted with solvent suggests high primary oxidation of oil during Soxhlet extraction (Jessinta et al., 2014). However, these peroxides values were less than 10 meq $\mathrm{O} 2 \mathrm{~kg}^{-1}$ oil, value, which characterises most conventional oils. Indeed, in previous studies, Yong et al. (2006) showed that the lower peroxide values $(10 \mathrm{meq} \mathrm{O} 2$ $\mathrm{kg}^{-1}$ oil) indicated an acceptable level of oxidation phenomenon.
The resulting oil from the two extraction methods have shown the highest SFAs and MUFAs contents in recovered oil after ebullition; and the highest PUFAs contents in oils extracted with the solvent. The Soxhlet method provided the highest PUFA, mainly due to the high operational temperature, solvent recycle and solvent/solute interactions (Abdolshahi et al., 2015). Oils obtained by hot-water flotation extraction showed the lowest PUFA values, despite the highest concentrations of SFAs and MUFAs. This is because oil samples were not chemically esterified before fatty acid analysis (Mezzomo et al., 2010). Natural esterification may occur during sample handling, allowing solvent polarity to influence oil fractionation. This can be explained by the use of high temperature and reflux in Soxhlet extraction overcoming the polarity effect during the extraction of PUFAs. Thus, in order to obtain L. siceraria oil with high quality, attention must be paid to the technique to oil extraction because some of them can be an agent of deterioration.

\section{CONCLUSION}

This study has showed that the oils present in roasted seeds and the sauce (roasted and boiled seeds) made from $L$. siceraria seeds are suitable for consumption. The oils present low values of quality index which meets FAO/ WHO recommendation and their fatty acids composition does not change, although there are potential sources of polyunsaturated fatty acids. For oil production, use of hot-water flotation process is recommended because use of solvent for extracting L siceraria oil makes it very unstable with high peroxide values and variation of fatty acids content.

\section{ACKNOWLEDGEMENT}

This research was financed by the Direction Générale de la Coopération au Développement (DGCD,Brussels, Belgium) and supervised by the Commission Universitaire pour le 
Développement (CUD, Brussels, Belgium) through PIC 2 project.

\section{REFERENCES}

Abdolshahi, A., Majd, M.H., Rad, J.S., Taheri, M., Shabani, A. and da Silva, J.A.T. 2015. Choice of solvent extraction technique affects fatty acid composition of pistachio (Pistacia vera L.) oil. Food Science Technology 52(4):2422 - 2427.

Abramovic, H., Butinar, B. and Nikolic, V. 2007. Changes occurring in phenolic content, tocopherol composition and oxidative stability of Camelina sativa oil during storage. Food Chemistry 104:903 909.

Achigan Dako, G.E., Fanou, N., Kouke, A., Avohou, H., Vodouhe, R.S. and Ahanchede, A. 2006. Évaluation agronomique de trois espèces de Egusi (Cucurbitaceae) utilisées dans l'alimentation au Bénin et élaboration d'un modèle de prédiction du rendement. Biotechnology Agronomy Society Environment 10:121 - 129.

AOAC. 2000. Official Method of Analysis 17th edition. Association of Official Analytical Chemists, Washington, DC, USA.

AOCS. 1997. Method Ch 5-91, Cd 18-90, Cd 8b-90. Ofûcial Methods and Recommended Practices of the American Oil Chemists' Society, 15th Ed., American Oil Chemists' Society Press, Champaign, IL.

AOCS. 2003. Official Method Cd 8-53. American Oil Chemists Society, Champaign, IL.

Badifu, G.I.O. 2001. Effect of processing on proximate composition, antinutritional and toxic contents of kernels from Cucurbitaceae species grown in Nigeria. Journal of Food Composition and Analysis 14:153 - 161.

Codex Alimentarius-Stan 210. 1999. Codex Alimentarius Commission, Recommended International Standard for Named Vegetable Oils. Rome, Italy, FAO and WHO.
Goswami, G., Bora, R. and Rathore, M.S. 2015. Oxidation of cooking oils due to repeated frying and human health. International Journal of Science Technology and Management 4(1):495501.

Jessinta, S., Azhari, H.N., Saiful, N.T. and Abdurahman, H.N. 2014. Impact of geographic variation on physicochemical properties of neem (Azadirachta indica) seed oil. International Journal of Pharmaceutical Sciences and Research 5(10):4406 - 4413.

Jung-Mi, Y. and Jeonghee, S. 2012. Fatty acid composition as a predictor for the oxidation stability of Korean vegetable oils with or without induced oxidative stress. Preventive Nutrition and Food Science 17 : $158-165$.

Lee, Y., Oh, S., Chang, J. and Kim, I. 2004. Chemical composition and oxidative stability of saûower oil prepared from saûower seed roasted with diûerent temperatures. Food Chemistry 84:1 - 6.

Loukou, A.L., Lognay, G., Barthelemy, J., Maesen, P., Baudoin, J-P. and Zoro, B.I.A. 2011. Effect of harvest time on seed oil and protein contents and compositions in the oleaginous gourd Lagenaria siceraria (Molina) Standl. Journal of the Science of Food and Agriculture 91:2073 - 2080.

Loukou, A.L., Lognay, G., Baudoin, JP.Kouame L.P. and Zoro, B.I.A. 2013. Effects of fruit maturity on oxidative stability of Lagenaria siceraria (molina) standl. seed oil extracted with hexane. Journal of Food Biochemistry 37:475 484.

Mariod, A.A., Ahmed, S.Y., Abdelwahab, S.I., Cheng, S.F., Eltom, A.M, Yagoub, S.O. and Shiou, W.G. 2012. Effects of roasting and boiling on the chemical composition, amino acids and oil stability of safflower seeds. International Journal of Food Science and Technology 47(8):1737 - 1743. Mezzomo, N., Mileo, B.R., Friedrich, M.T., Martínez, J. and Ferreira, S.R.S. 2010. 
Supercritical fluid extraction of peach (Prunus persica) almond oil: process yield and extract composition. International Journal of Pure and Applied Bioscience 101:5622 - 5632.

Milind, P. and Satbir, K. 2011. Is bottle gourd a natural guard? International Research Journal of Pharmacy 2(6):13 - 17.

Morimoto, Y. and Mvere, B. 2004. Lagenaria siceraria (Molina) Standl. In: PROTA 2: Vegetables/Légumes. Grubben, G.J.H. and Denton, O.A. (Eds.). [CD-Rom]. PROTA, Wageningen, The Netherlands.

Morrisson, W.R. and Smith, L.M., 1964. Preparation of fatty acid methyl esters and dimethylacetals from lipids with boron ûuoride-methanol. Journal of Lipid Research 5:600 - 608.

Ntsomboh-Ntsefong, G., Likeng-Li-Ngue, B.C., Bell, J.M., Tabi-Mbi, K., Di-Maissou; J.A., Kenmogne, S.T., Mana, N.S., NgalleBille, H. and Youmbi, E. 2016. Effects of dietary fatty acids on human health: Focus on palm oil from Elaeis guineensis Jacq. and useful recommendations. Food and Public Health 6(3):75-85.

O'Brien, R.D. 2009. Fat and oil. CRC Press, New York, USA.
Onyeike, E.N. and Acheru, G.N. 2002. Chemical composition of selected Nigerian oil seeds and physicochemical properties of the oil extracts. Food Chemistry 77: 431 $-437$.

Popa, M., Glevitzky, I., Dumitrel, G.-A., Glevitzky, M. and Popa, D. 2017. Study on peroxide values for different oils and factors affecting the quality of sunflower oil. Series E-Land Reclamation Earth Observation \& Surveying Environmental Engineering 6:137 - 140.

Richardsa, A., Wijesundera, C. and Salisbury, P. 2005. Evaluation of oxidative stability of canola oils by headspace analysis. Journal of the American Oil Chemists' Society 82: 869 - 874.

Warra, A.A. 2011. Sesame (Sesamum indicum L.) seed oil methods of extraction and its prospects in cosmetic industry. Bayero Journal of Pure and Applied Sciences 4(2): $164-168$.

Yong, Y.O. and Salimon, J. 2006. Characteristics of Elateriopermum tapos seed oil as a new source of oilseed. Journal Industrial Crops and Products 24:146 151. 